\title{
Evaluation of the self-cemeting effect of Construction and Demotion Waste (CDW) on mechanical performance over time for pavement support layers purpose
}

\author{
Avaliação do efeito da auto-cimentação dos Resíduos de \\ Construção Civil (RCC) sobre o desempenho mecânico ao \\ longo do tempo para o emprego em camadas de suporte de \\ pavimentos
}

\section{Fabiana Artuso J uliana Azoia Lukiantchuki}

\section{Abstract}

he problem related to the generation of construction and demolition waste (CDW) is directly associated with its high volume and irregular disposal, especially when such waste is disposed of in landfills. Therefore, it is increasingly important to encourage the reuse of this material, especially in large-scale projects. However, the use of this waste depends on the different constituent materials, which show a wide variability. Within this context, the objective of this work was to study the mechanical performance of construction and demolition waste over time aiming at the use in pavement support layers. Two samples were evaluated, one composed exclusively of construction waste (CDW_1) and the other composed of a soil-waste mixture (S_CDW), with $50 \%$ of each material. The tests evaluated the strength of the materials over a curing period from 0 to 224 days. The results clearly indicate an increase in strength and stiffness over time. The CDW_1 samples indicated a more significant increase. The analyses indicated that this behavior occurs due to the effect of selfcementing properties that occur in this type of waste. The results indicate a benefit in terms of strength when using this type of waste either alone or mixed with soil.

Keywords: Construction and demolition waste. Self-cementing properties. Strength. Stiffness. Pavements.

\section{Resumo}

O problema relacionado a geração de resíduos de construção civil (CDW) está diretamente associado à sua elevada geração e disposição irregular, sobretudo quando tais resíduos são dispostos em aterros sanitários. Desta forma, torna-se cada vez mais importante o incentivo do reaproveitamento deste material, sobretudo em obras de grande consumo. No entanto, a aplicação desses resíduos depende dos diferentes materiais constituintes, que tem como característica principal a ampla variabilidade. Desta forma, este trabalho teve como objetivo o estudo do desempenho mecânico dos resíduos de construção civil ao longo do tempo visando o seu emprego em camadas de suporte de pavimentos. Foram avaliadas duas amostras, sendo uma composta exclusivamente por resíduo (CDW_1) e a outra composta por solo e resíduo (S_CDW), com 50\% para cada material. Os ensaios foram conduzidos avaliando a resistência com período de 0 a 224 dias de cura. Os resultados indicaram nitidamente o aumento de resistência e da rigidez ao longo do tempo. As amostras $C D W \_1$ indicaram um aumento mais significativo. As diferentes análises indicaram que este comportamento ocorre devido ao efeito de auto-cimentação que acontece neste tipo de resíduo. Os resultados indicam um benefício, em termos de resistência, quando se utiliza esse tipo de resíduo isoladamente ou misturado com solo.

Recebido em 15/12/17

Aceito em 27/08/18
Palavras chave: Resíduos de construção civil. Propriedades cimentantes. Resistência. Rigidez. Pavimentação.

ARTUSO, F.; LUKIANTCHUKI, J. A. Evaluation of the self-cemeting effect of Construction and Demotion Waste (CDW) 59 on mechanical performance over time for pavement support layers purpose. Ambiente Construído, Porto Alegre, v. 19, n. 2, p. 59-77, abr./jun. 2019. 


\section{Introduction}

The generation of construction and demolition waste (CDW) has become problematic in urban centers, due to the associated scarcity of disposal sites, the adoption of inefficient, management measures, as well as problems of public sanitation and environmental contamination often caused by irregular disposal. The recycling of waste generated in construction and demolition projects has been encouraged, above all, in order to conserve the large quantities of natural resources typically used in engineering projects.

With the increasing use of CDW for civil engineering applications, there is a need to understand its strength behaviors: a fundamental parameter for justifying its use. Arm (2001) observed that an increase in strength occurs with a decrease in permeability in pavement layers that incorporate recycled aggregates. This fact is directly related to probable self-cementing properties of the material, given that its heterogeneity can provide hydration and pozzolanic reactions. The influence on mechanical behavior due to the self-cementing effect of these materials can be evaluated, for example, based on the determination of the change in the resilient modulus and unconfined compressive strength over time (BLANKENAGEL, 2005). This self-cementing effect is associated with the physical characteristics and the chemical and mineralogical composition of the waste material, since it is composed of different types of materials that can influence its behavior with respect to its mechanical strength, water absorption and density (GÓMEZ, 2011).

Arm (2001) compared the behavior of a recycled concrete aggregate and a natural aggregate, normally used in pavement base layers, by means of a cyclic triaxial test. The result of that study found that the recycled aggregate showed a tendency for the resilient modulus to increase over time. On the other hand, the natural aggregates tested with the same method did not show a similar increase. Sangiorgi, Lantieri and Dondi (2014) evaluated the performance of construction waste in an experimental embankment. The authors confirmed an increase in stiffness over time, attributing this behavior to self-cementing properties, and highlighting the positive mechanical characteristics of CDW when compared with natural aggregates.

Poon, Qiao and Chan (2006) evaluated the selfcementing effect on the unconfined compressive strength for different fractions of CDW submitted to curing periods of 1 and 7 days. The finer fractions $(<0.15 \mathrm{~mm}$ and $0.3-0.6 \mathrm{~mm}$ ) presented greater unconfined compressive strength when compared to the other fractions analyzed. The authors explained that the presence of $\mathrm{C} 2 \mathrm{~S}$ in the finer fractions indicated that the compound had not yet completed hydration, which may be a possible cause for the greater tendency of these fractions to present selfcementing properties.

The increase in unconfined compressive strength of CDW over time is linked to the self-cementing phenomenon of the material itself. This may be related to the intrinsic properties of the material, such as cement particles that have not yet come into contact with water, which, after crushing and transformation into recycled aggregate, may then have contact with water and incur new hydration reactions, as well as the presence of minerals and chemical compounds found in cement. Thus, the physical, chemical and mineralogical characterization of the CDW is essential for analyzing the cause of the self-cementing effect of the material over time.

The objective of this study was to evaluate the mechanical performance of construction and demolition waste over time as a function of the occurrence of the self-cementing effect of such material. For this, samples composed exclusively of CDW and a soil-CDW mixture (in a 50:50 proportion) were analyzed. The self-cementing effect was evaluated through physical and chemical characterization tests, unconfined compressive strength tests for different curing times, and scanning electron microscopy. The results enabled the evaluation of the behavior of these samples and the effects of the addition of these materials to natural soil.

\section{Geotechnical characterization of CDW samples}

The samples of construction waste (CDW) were collected at the Mauá Recycling Plant, located in the city of Maringá, Paraná, Brazil (Figure 1). In this recycling site the wastes are separated in different mounds according to their composition. In the present work, the selected waste is composed of wastes from concrete, cementitious mortar and soil. The samples were air-dried until reaching hygroscopic moisture content and were subsequently stored in containers protected from contact with other materials. For this research, two different CDW samples were used:

(a) waste material passed through a $0.42 \mathrm{~mm}$ sieve, referred to as CDW_1; and

(b) waste material with particles between 0.01 $5.0 \mathrm{~mm}$ in diameter, referred to as CDW_2. 
Due to its high granularity and lack of cohesion, sample CDW_2, was mixed with a sandy residual soil (S) collected in the city of Mandaguaçu, Paraná, Brazil. In terms of dry mass, the soil was mixed with the waste material (S_CDW) in the proportion of $50 \%$ soil and 50\% CDW_2, providing cohesion to the mixture and enabling the evaluation of the strength of this matrix.

The geotechnical characterization tests of the materials were carried out according to the recommendations of the Brazilian Association of Technical Standards (ABNT, 2017): particle density, grain size distribution (ABNT, 2018) and compaction tests (ABNT, 2016a). The results presented in Table 1 indicate that the particle density of the CDW is slightly higher than that of the soil. The influence of CDW on the soil matrix in relation to the particle density is relatively low.

Figure 2 and Table 1 present the results of the grain size distribution of the studied materials. The results indicate that samples CDW_1 and CDW_2 are basically composed of medium sand and coarse sand, respectively. Due to the low presence of clay and silt fractions, the liquid and plasticity limits could not be determined. As expected, the incorporation of CDW into the soil matrix caused an increase in the gravel fraction and a decrease in the clay fraction (Table 1).

In the standardized compaction test based on NBR 7182 (ABNT, 2016a) different energy levels are established, and in this work standard effort $\left(600 \mathrm{~kJ} / \mathrm{m}^{3}\right)$ was used. Standard effort was imposed by applying 26 blows per layer, and 3 layers were used to compose each point. The dry density $\left(\rho_{d}\right)$ is the ratio of the solid mass to the total volume, which represents the density when the degree of saturation is equal to zero. The compaction parameters $\left(\rho_{\mathrm{dmax}}\right.$ and $\mathrm{w}_{\mathrm{op}}$ ) estimated for the samples are shown in Figure 3 and Table 1.

\section{Figure 1 - Recycling site and construction waste}

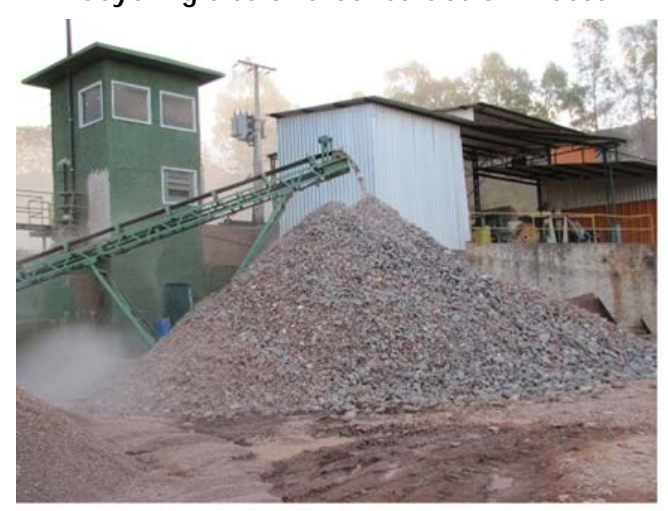

(a) Recycling Site
The compaction curve of CDW_2 shows a behavior similar of permeable soils with free drainage. The high volume of voids (Figure 4) facilitates the exit of water when the particles are compressed at a higher density. In this case, the dry density remains constant, regardless of the increase in moisture content. For this type of material, the optimum moisture content corresponds to the point at which the saturation of the voids with water occurs. Therefore, the maximum dry density was $1.540 \mathrm{~g} / \mathrm{cm}^{3}$, determined by the average of the values. This value is lower than granular materials, which shows dry density between 1.800 to 2.100 $\mathrm{g} / \mathrm{cm}^{3}$. The optimum moisture content was $19.40 \%$, adopted as the maximum possible moisture content to be placed in the sample and compacted without exuding water in the lower part of the compaction cylinder.

Arulrajah, Piratheepan and Disfani (2013) also observed the same behavior for some CDW samples, i.e., the dry density showed insignificant variation with the increase in the water content. The authors attributed this behavior to the low water absorption of the material and to the presence of the smooth surfaces of the materials.

The results also indicated that for the S_CDW mixture, the compaction behavior was similar to the natural soil behavior. The dry density increased gradually with increasing moisture content until reaching a maximum value, referred to as maximum dry density $\left(\rho_{\text {dmax }}\right)$. For this dry density the moisture content is considered the optimum point $\left(\mathrm{w}_{\mathrm{op}}\right)$. The parameters obtained for the natural soil were maximum dry density and optimum moisture content of $1.872 \mathrm{~g} / \mathrm{cm}^{3}$ and $13.20 \%$, respectively, and the degree of saturation equal to $81 \%$. For the S_CDW mixture, the maximum dry density was $1.850 \mathrm{~g} / \mathrm{cm}^{3}$, the optimum moisture content equal to $13.20 \%$ and the degree of saturation equal to $77 \%$.

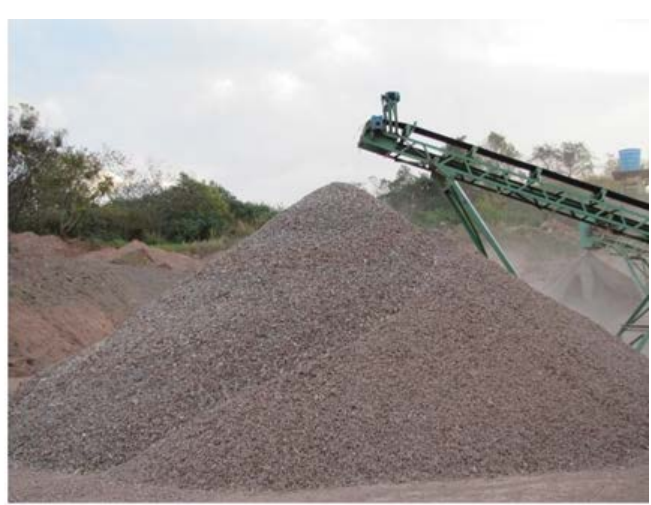

(b) Construction waste 
Table 1 - Results of geotechnical characterization of materials

\begin{tabular}{c|c|c|c|c}
\hline Geotechnical parameters & CDW_1 & CDW_2 & S & S_CDW \\
\hline $\mathrm{D}_{10}(\mathrm{~mm})$ & 0.013 & 0.320 & - & - \\
$\mathrm{D}_{30}(\mathrm{~mm})$ & 0.150 & 0.710 & 0.09 & 0.130 \\
$\mathrm{D}_{60}(\mathrm{~mm})$ & 0.250 & 1.600 & 0.190 & 0.350 \\
$\mathrm{C}_{\mathrm{u}}$ & 19 & 5 & - & - \\
$\mathrm{C}_{\mathrm{c}}$ & 7 & 1 & - & - \\
Gravel content $(\%)$ & - & 32.5 & - & 15.0 \\
Sand content $(\%)$ & 80.6 & 64.2 & 76.5 & 64.3 \\
Silt content $(\%)$ & 15.2 & 3.3 & 6.2 & 6.9 \\
Clay content $(\%)$ & 4.2 & - & 17.3 & 13.8 \\
SUCS classification & $\mathrm{SP}-\mathrm{SC}$ & $\mathrm{SP}$ & $\mathrm{SC}$ & $\mathrm{SC}$ \\
Particle density $\left(\rho_{\mathrm{s}}\right)-$ fine fraction $\left(\mathrm{g} / \mathrm{cm}^{3}\right)$ & 2.786 & 2.813 & 2.690 & 2.767 \\
Maximum dry density $\left(\rho_{\mathrm{dmax}}\right)\left(\mathrm{g} / \mathrm{cm}^{3}\right)-$ standard effort & 1.589 & 1.540 & 1.872 & 1.850 \\
Optimum moisture content $\left(\mathrm{w}_{\mathrm{op}}\right)(\%)-$ standard effort & 19.70 & 19.40 & 13.20 & 13.80 \\
\hline
\end{tabular}

Where:

$D_{10}, D_{30}$, e $D_{60}$ are the diameters corresponding to 10,30 and $60 \%$ of the material, respectively; and $\mathrm{C}_{\mathrm{u}}$ and $\mathrm{C}_{\mathrm{c}}$ are the coefficients of uniformity and curvature, respectively.

The coefficients are estimated by: $C_{u}=\frac{D_{60}}{D_{10}}$ and $C_{c}=\frac{\left(D_{30}\right)^{2}}{\left(D_{60} \times D_{10}\right.}$.

Figure 2 - Grain size distribution

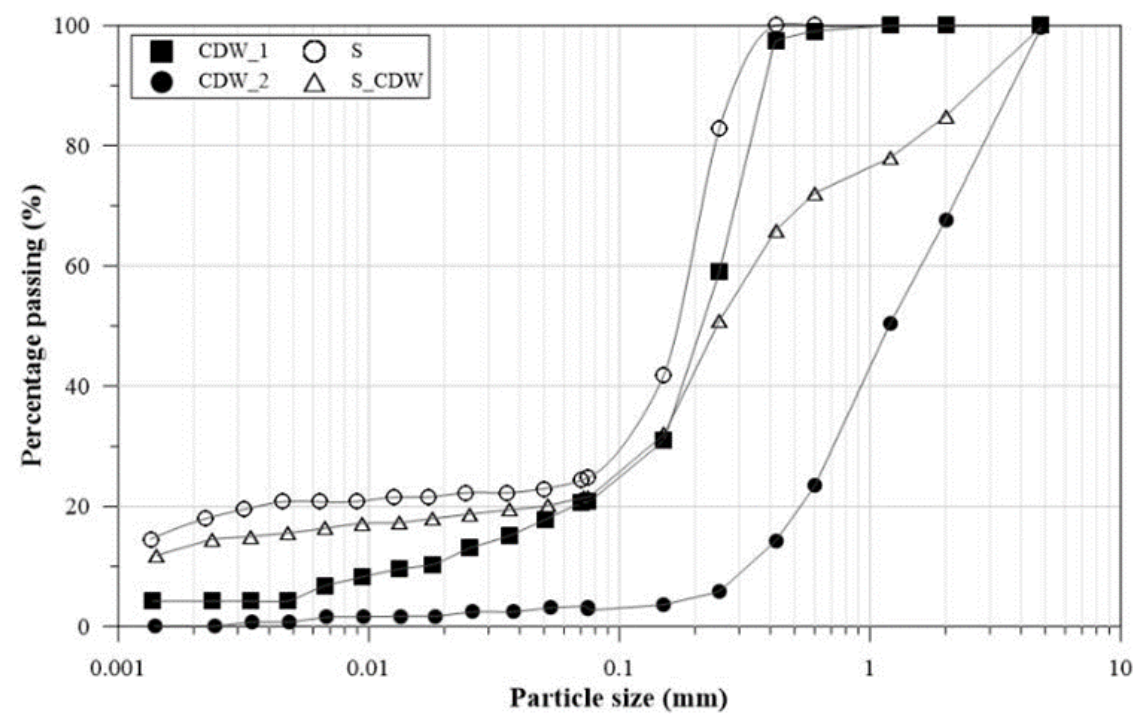

The CDW_1 sample presented a curve format similar to the natural soil and the S_CDW mixture. The grain size composition indicates a material less granular than CDW_2 and with the presence of silt, therefore more similar to the grain size distribution of the natural soil. The maximum dry density and optimum moisture content was $1.589 \mathrm{~g} / \mathrm{cm}^{3}$ and $19.70 \%$, respectively, and degree of saturation equal to $73 \%$.

\section{Chemical and mineralogical characterization of the CDW}

In order to evaluate the chemical and mineralogical characteristics of the CDW, the following tests were performed: pozzolanic activity, $\mathrm{pH}$ and X-ray diffraction (XRD) tests. The pozzolanic activity test was carried out at the Technological Research Institute (IPT) of São Paulo, through the Chapelle Method (ABNT, 2010). The tests were run on samples CDW_1 and CDW_2. The material was dried at $105{ }^{\circ} \mathrm{C}$ until constant mass, then milled until the material was totally passed through the $0.045 \mathrm{~mm}$ sieve.

The method is based on the determination of lime consumption related to the amorphous or vitreous phase of the pozzolanic materials. According to NBR 15895 (ABNT, 2010), the additions may be considered pozzolan on being incorporated into the Portland cement composition when the consumption is greater than $436 \mathrm{mg} \mathrm{Ca}(\mathrm{OH})_{2} / \mathrm{g}$. Table 2 shows the consumption of calcium 
hydroxide $\left(\mathrm{Ca}(\mathrm{OH})_{2}\right)$ found in the samples analyzed. Although the grain size distribution of the materials is different, the results of pozzolanic activity indicated very close values for the samples analyzed. The values of calcium hydroxide consumption were lower than the minimum value established in the standard. The pozzolanic reaction is useful because it converts the relatively soluble calcium hydroxide into $\mathrm{C}-\mathrm{S}-\mathrm{H}$ which increases strength and reduces the permeability of the material.

Motta (2005) also found values lower than the values established by the standard. However, the author does not rule out the possibility of the CDWs contributing to the increased mechanical strength of the pavement. This is because the minimum consumption index, established in the standard, was defined for the concrete, which presents a very different strength behavior when compared to the new materials that have been developed. Moreover, the selected wastes are composed of wastes from concrete, cementitious mortar and soil. The absence of ceramic materials reduces the pozzolanic activity because the bricks and ceramic materials are responsible to pozzolanic activity with the $\mathrm{Ca}(\mathrm{OH})_{2}$ found in the hydrated cementitious materials.
Gómez (2011) evaluated the pozzolanic activity of CDW with Portland cement and also found that the material does not meet the requirements of the standard. However, they stressed that the unconfined compressive strength of the material reached a reasonable value.

The $\mathrm{pH}$ test was performed with the material passing through the $2.00 \mathrm{~mm}$ sieve, using $20 \mathrm{~g}$ of the material in $100 \mathrm{ml}$ of aqueous solution. The $\mathrm{pH}$ readings were determined at time intervals of 10 , 20, 30, 60, 120, 240, 1440, 2880 and 4320 minutes after the mechanical stirring.

Figure 5 shows the variation in $\mathrm{pH}$ as a function of time, where the $\mathrm{pH}$ for sample $\mathrm{CDW} \_2$ was higher than the value obtained for sample CDW_1. The mean values were 9.72 and 11.03 for samples CDW_1 and CDW_2, respectively. The CDW_1 shows a $\mathrm{pH}$ value lower than $\mathrm{CDW}$ 2, probably because this sample is composed of small fractions of concrete and cementitious mortar, possibly carbonated. The CDW_2 sample is composed of particles larger than the CDW_1, where noncarbonated fractions can be found or the presence of anhydrous grains.

Figure 3 - Compaction curves of the samples

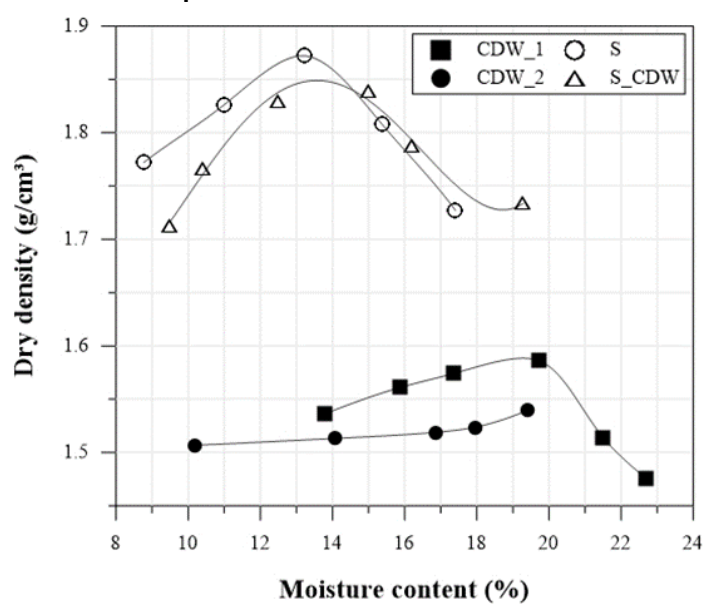

Figure 4 - Compaction for sample CDW_2

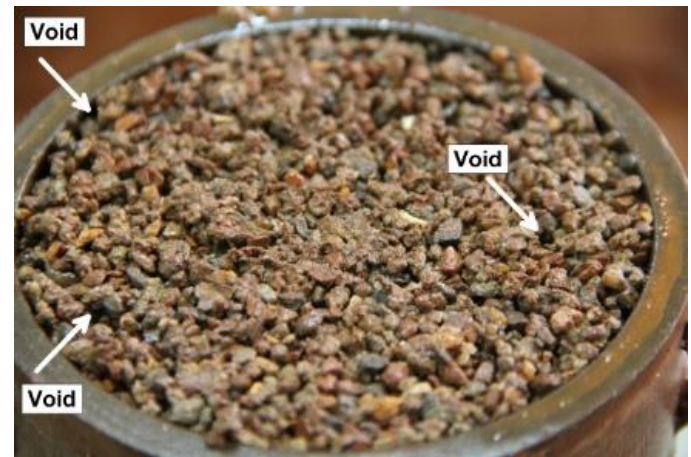

Evaluation of the self-cemeting effect of Construction and Demotion Waste (CDW) on mechanical performance over time for pavement support layers purpose 
Table 2 - Results of pozzolanic activity and pH

\begin{tabular}{c|c|c}
\hline Parameters & CDW_1 & CDW_2 \\
\hline (mg Ca(OH) $)_{2} /$ g sample $)$ & 168 & 160 \\
pH & 9.72 & 11.03 \\
\hline
\end{tabular}

Figure 5 - Data obtained during the pH test for CDW samples

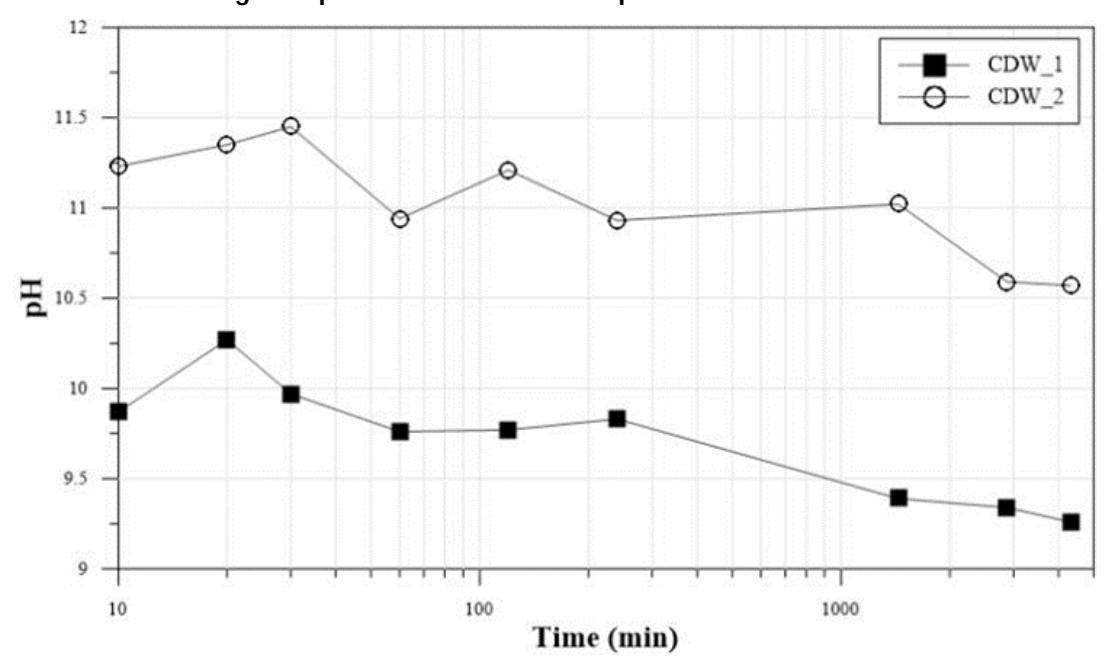

The low performance of the pozzolanic activity of the material may be directly related to absence of amorphous silica, which is from burning of bricks and tiles. As the waste is composed of concrete and cementitious, mortar the most part of the grains of cement are already hydrated. Poon, Qiao and Chan (2006) also obtained higher $\mathrm{pH}$ values for granular CDWs.

According to Gómez (2011), who obtained pH equal to 11.2 for CDW samples, a high $\mathrm{pH}$ environment could alter the silica minerals. This environment is effective for achieving the stabilization of clays with calcium oxide through pozzolanic reactions where calcium silicate is hydrated, and cementitious materials are formed using the modified silica of the clay minerals. Blankenagel (2005) comments that the pozzolanic reaction can only occur at $\mathrm{pH}$ levels above 10 , because it is in this medium that the silica becomes soluble. Although the $\mathrm{pH}$ and pozzolanic activity tests for the S_CDW sample were not performed, these results can contribute with the interpretation of self-cementing waste behavior. This is because lateritic soils are composed of kaolinite, which is soluble in water and allows the reaction of alkali of the anhydrous grains present in the concrete and cementitious mortar of CDW.

To perform the XRD test, the CDW_1 sample was passed through a No. 200 sieve $(0.075 \mathrm{~mm})$ and the CDW_2 sample through a No. 100 sieve $(0.15 \mathrm{~mm})$. The minerals were identified by means of an X-ray diffractometer, of the brand Bruker model D8
Advance. $\mathrm{CuK} \alpha(40 \mathrm{kV}$ and $35 \mathrm{~mA})$, with angular range of $0^{\circ}$ (2 Theta initial) and $80^{\circ}$ ( 2 Theta final), angular velocity of $1^{\circ}$ per minute were used as test parameters. Mineral identification was performed using X'Perth HighScore software.

The diffractograms of the soil samples, CDW_1 and CDW_2, are presented in Figure 6. In the case of the soil, the predominant mineral is quartz coming from basaltic rocks, the presence of hematite was also detected, due to the iron oxides and hydroxides, and of kaolinite which is the predominant clay in lateritic soils, as is the case with this soil. In the case of the waste materials, the diffractograms were similar, where the predominant mineral is calcite, which is characterized as one of the main cement minerals present in sedimentary rocks. The predominant presence of this mineral is consistent since there was a large quantity of materials containing cement, such a concrete, visible in the waste materials. The presence of calcite is due to the process of carbonation of the calcium silicates and the hydroxide of calcium derived from the cement of concretes and cementitious mortars. The presence of quartz from the natural silica found in sands was also confirmed. The results are consistent with results presented by other researchers. Evangelista et al. (2015) identified the presence of calcite and quartz in all fractions of fine recycled aggregate (FRA) from concrete. Gómez (2011) found quantities of silicates, such as quartz, carbonates, such as calcite, and clay-rich silica and aluminum, such as ilite. 
Figure 6 - XDR analysis of the soil, CDW_1 and CDW_2
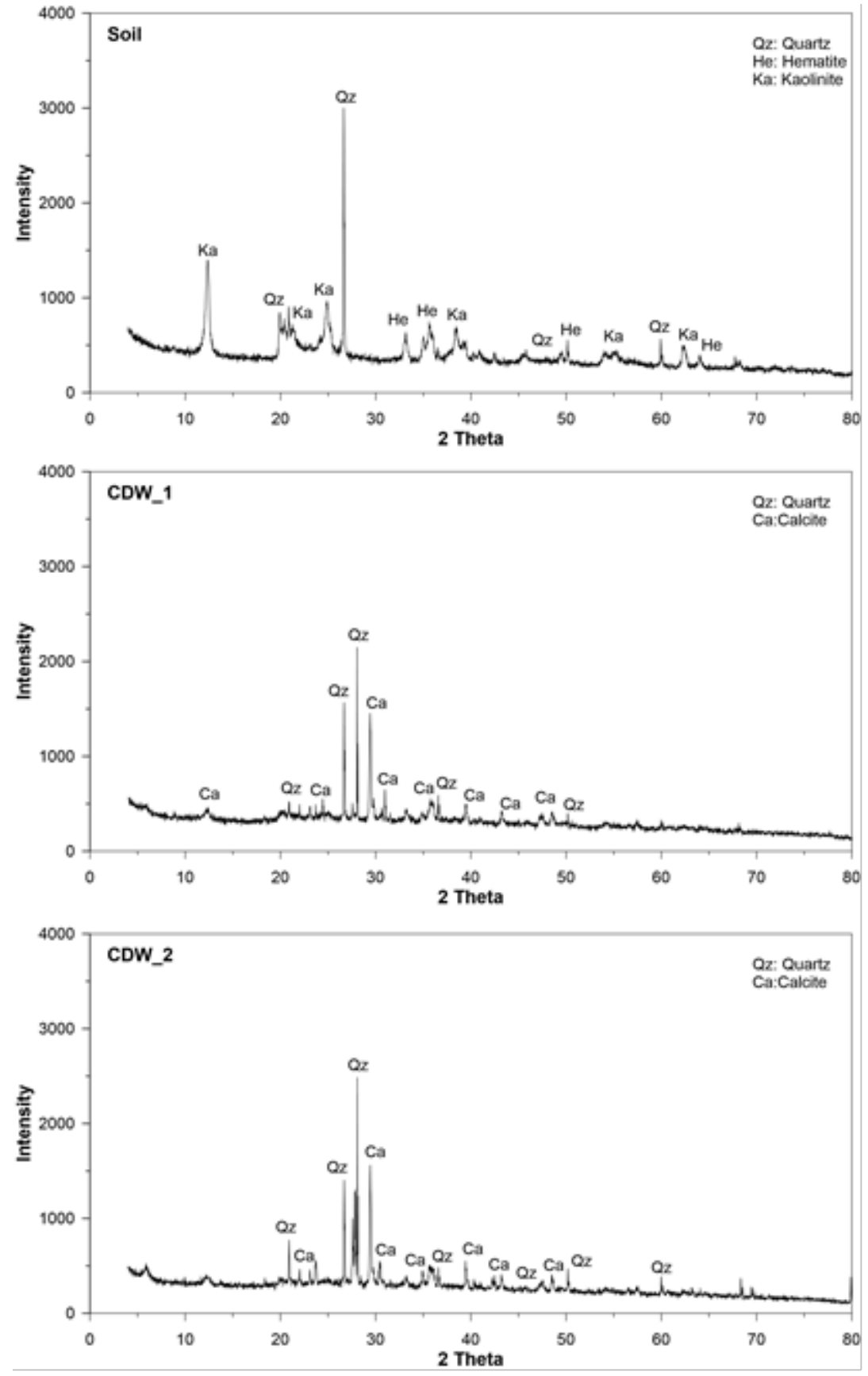

\section{Methodology for the evaluation of self-cementing properties}

The methodology used to evaluate the selfcementing properties of the waste is presented in the flowshart of Figure 7a. Test specimens (Figure 7b) were molded in cylindrical form with a $50 \mathrm{~mm}$ diameter and $100 \mathrm{~mm}$ height for the CDW_1 and S_CDW samples. The S_CDW mixture was prepared, in terms of dry mass, using a 50:50 ratio (50\% soil and 50\% CDW_2). The choice of this proportion was made based on research done previously by Silva et al. (2015).

The compaction of the specimens was performed in 3 layers approximately $35 \mathrm{~mm}$ thick with adequate scarification between the layers in order to increase the integration and the adhesion between the superimposed layers. After compaction, the top was leveled so as to obtain a smooth horizontal surface and the specimen was weighed and packed in a plastic bag to be stored in the wet chamber for curing times of $0,3,7,14,21,28,56,112$ and 224 days prior to axial compressive strength tests. 
Figure 7 - Methodology for evaluation of the self-cementing effect

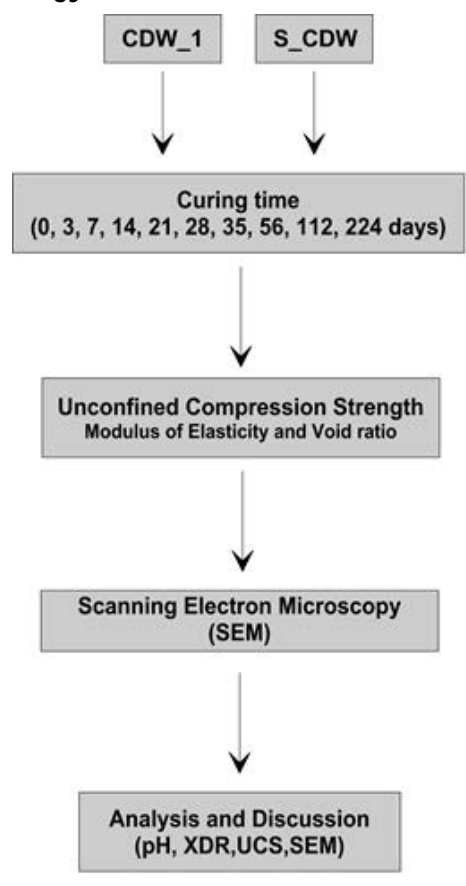

(a) Methodology of the research

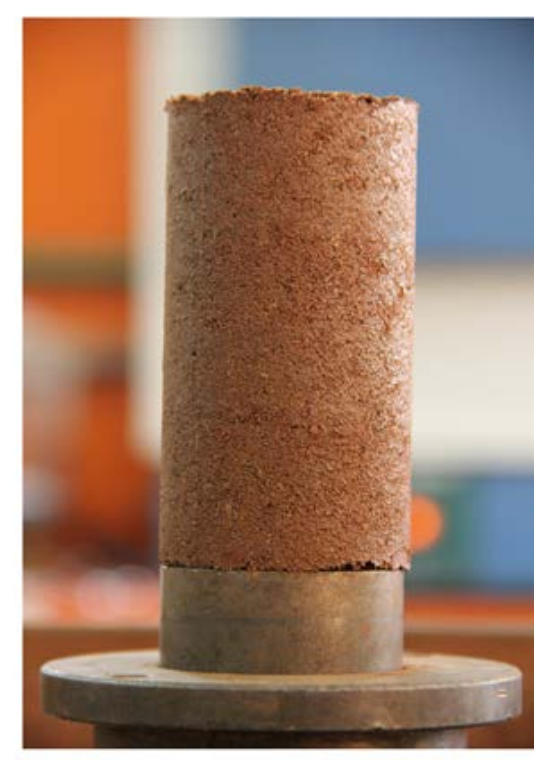

(b) Sample

At least three (3) specimens were molded for each of the established cure times. In order to evaluate the effect of the addition of the construction and demolition waste on the soil matrix, 3 specimens of the soil sample were molded. Since the soil used does not have cementitious properties, the specimens molded with this material were not subjected to the curing period and were ruptured on the same molding day (0 days).

The specimens were appropriately controlled in relation to mass, volume and moisture content. After the curing time and before the axial compressive strength tests, the specimens were weighed again and, after rupture, the moisture content was measured. This procedure was carried out to evaluate whether a variation in the moisture content during the curing time occurred, influencing the strength values. In this way, the values of axial compressive strength can be related exclusively to the properties of the materials used.

The parameters established for compaction of the test specimens were the maximum dry density and the optimum moisture content for the curve corresponding to the material used (Table 1 and Figure 3). The moisture content was determined by the ABNT oven method (ABNT, 2016b), with a temperature ranging from 105 to $110^{\circ} \mathrm{C}$ and a 24 hour period for complete drying of the material.

The dry density $\left(\rho_{\mathrm{d}}\right)$ was determined by Equation (1) and Equation (2). The relationship between the

dry density of the specimen $\left(\rho_{\mathrm{d}}\right)$ and the maximum dry density $\left(\rho_{\text {dmax }}\right)$ obtained by the compaction test provides the degree of compaction (DC) (Equation 3). Accordingly, in this research, the specimens were molded with the same degree of compaction, avoiding the influence of this parameter on the strength values. The higher the degree of compaction, the smaller the void volume of the sample and consequently the greater its strength. In this work a degree of compaction was established between $95-100 \%$ and the moisture content between $\pm 2 \% \mathrm{w}_{\mathrm{op}}$.

$$
\rho_{d}=\frac{\rho}{1+w}
$$

Where:

$\rho\left(\mathrm{g} / \mathrm{cm}^{3}\right)=$ the density of the test specimen; and $\mathrm{w}=$ the moisture content.

$$
\rho=\frac{M}{V}
$$

Where:

$\mathrm{M}=$ the mass ( $\mathrm{g}$ ) of the specimen; and

$\mathrm{V}=$ the volume.

$$
D C=\frac{\rho_{d}}{\rho_{d \max }}
$$


The axial compressive strength tests were carried out by applying the load in constant increments where the force values were monitored through a dynamometer ring properly calibrated. In addition, displacement was monitored through a mechanical dial indicator. Figure 8 shows the unconfined compressive strength test.

After the unconfined compression strength tests, parts of the specimens, duly identified, were selected for scanning electron microscopy (SEM) tests. SEM was carried out with the objective of obtaining information about the morphology of the test specimens, evaluating the internal structure in order to observe possible connections and structures formed between particles due to the self-cementing effect of the material.

The tests were carried out in the Laboratory of Microscopy of the Brazilian Center for Physical Research (CBPF) in the city of Rio de Janeiro. For the electron microscopy test, MEV JSM 6460LV, JEOL brand, model EDS NORAN SYSTEM SIX MODEL 200 was used. The prepared samples were inserted inside the scanning electron microscope for image capture.

The void ratio of the specimens (e) were estimated through Equation (4), where volume of void is the sum between air and water and the volume of solid is the volume filled by particles. The water volume was estimated adopting water density as $1 \mathrm{~g} / \mathrm{cm}^{3}$ and the particle density was obtained in experimental tests (Table 1).

$e=\frac{V_{v}}{V_{s}}$

Where:

$\mathrm{Vv}=$ the volume of void $\left(\mathrm{cm}^{3}\right)$; and

$\mathrm{Vs}=$ the volume of solid $\left(\mathrm{cm}^{3}\right)$. The void ratio is not expressed as a percentage.

The modulus of elasticity (E) or Young's modulus, is a mechanical parameter for evaluating the stiffness of the material, which is considered an intrinsic property of the material since it depends, among other aspects, on the chemical composition and the microstructure. The determination of this parameter can be established through the relationship between the stress $(\sigma)$ and the deformation $(\varepsilon)$ obtained from the curve of the strength of material test (Equetion 5).

$$
E=\frac{\sigma}{\varepsilon}
$$

For the tests carried out in this research, the tangent modulus $\left(E_{t}\right)$, for a specific point (elastic region), was determined by evaluating the relationship between the stress corresponding to $50 \%$ of the rupture stress $\left(\sigma_{50 \%}\right)$ and the strain $\left(\varepsilon_{50 \%}\right)$ for a given point (Figure 9).

Figure 8 - Unconfined compressive strength test

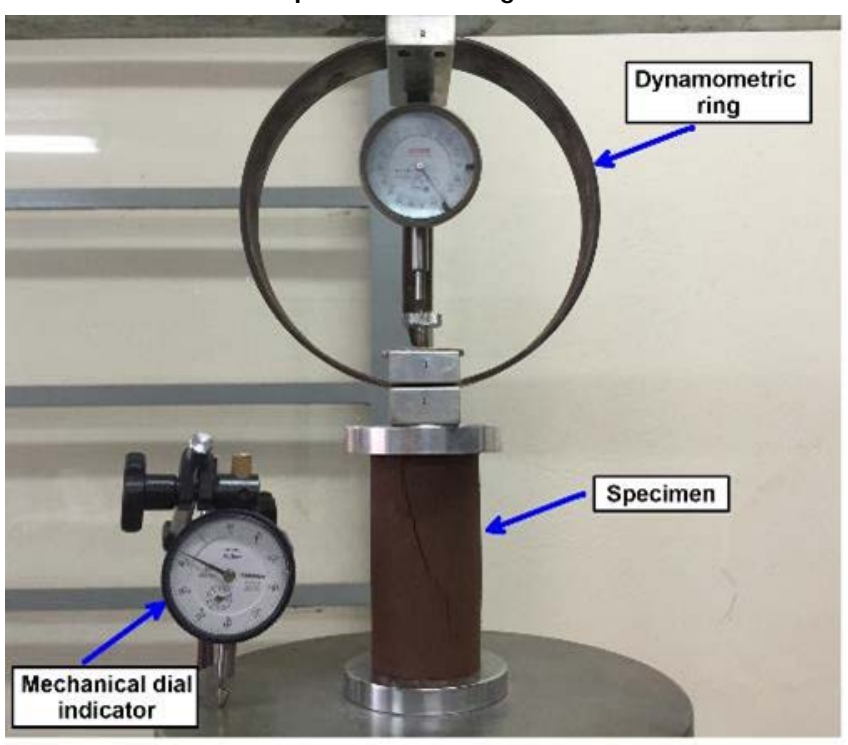

(a) Unconfined Compression Test

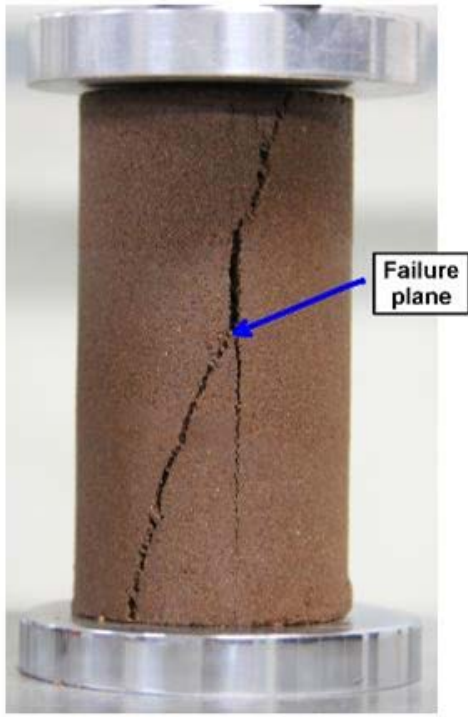

(b) Specimen after the test 
Figure 9 - Unconfined compressive strength test

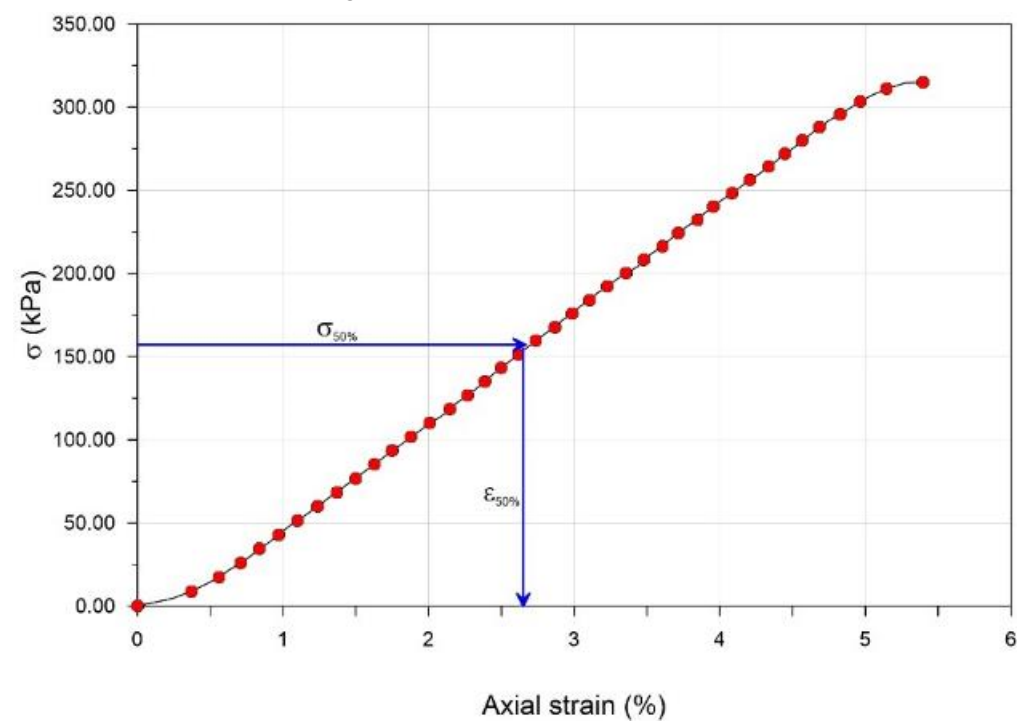

\section{Results and discussion}

\section{Dry density over time}

The dry density of the specimens was determined at the time of molding and after the specimen had ruptured. Figure 10 shows the variation for the CDW_1 sample, where the curing period did not alter the dry density of the specimens and consequently the degree of compaction. The results indicate that most of the test specimens were molded with a degree of compaction above $100 \%$ and were very close, with a coefficient of variation equal to $1.73 \%$ and $1.84 \%$ for the molding and rupture conditions, respectively. The relative error was determined with respect to the value of $\rho_{\mathrm{dmax}}$, obtaining maximum values in modulus equal to $5.73 \%$ and $6.29 \%$ for the conditions of molding and rupture, respectively.

Figure 11 shows the variation in the dry mass for the S_CDW sample, where, in general, the curing period did not change the dry density of the specimens and consequently the degree of compaction. The graph indicates a small increase in dry density for a ruptured specimen at 112 days of cure and a significant decrease in dry density for a ruptured specimen at 224 days of cure. These variations can occur because the specimens are packed in a humid chamber subject to humidity variations. However, since the specimens were generally close to the molding conditions, the packaging in plastic bags was considered to be efficient against variations in moisture content.

The results showed a coefficient of variation equal to $1.30 \%$ and $1.76 \%$ for the molding and rupture conditions, respectively. The relative error was determined in relation to the value of $\rho_{\mathrm{dmax}}$, obtaining maximum values in modulus equal to $4.05 \%$ and $6.43 \%$ for the conditions of molding and rupture, respectively.

Therefore, the specimens presented a very close degree of compaction, and the variation in the molding conditions are assumed to have had no effect on the strength values presented below.

\section{Unconfined Compressive Strength (UCS)}

Figure 12 shows the unconfined compressive strength results for the CDW_1 sample, where a well-defined increase in strength over time (Figure 12a) is observed for the sample of compacted waste material under standard effort conditions. The polynomial fit proved to be satisfactory when the average values of unconfined compressive strength were used (Figure 12b).

The unconfined compressive strength for the S_CDW mixture was evaluated for the curing period of up to 112 days. Figure 13 shows unconfined compressive strength results for the S_CDW mixture, in which the strength over time also increased as a function of curing time, however, this behavior was not as well-defined (Figure 13) as in the case of the pure CDW sample (Figure 12). The coefficient of variation for the samples tested with a curing time of 35 days was the highest (18.7\%) and therefore these results were disregarded for point adjustment (Figure 13b). The results obtained after 21 days of cure indicated a trend of strength stabilization. 
Figure 10 - Dry density versus cure time (CDW_1)

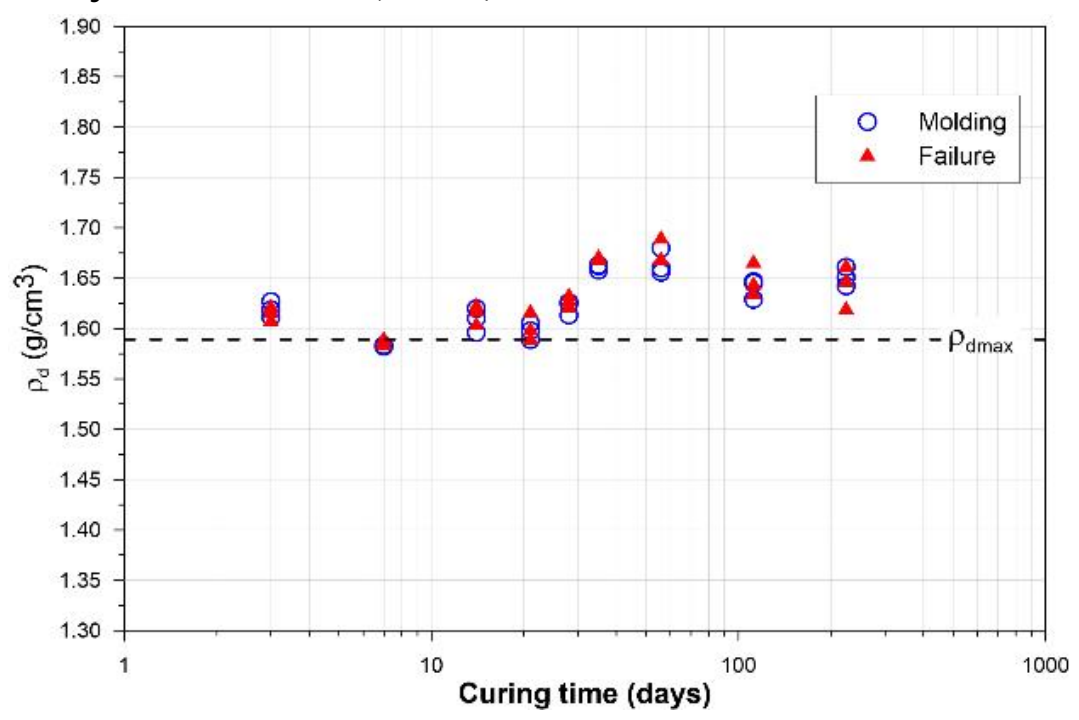

Figure 11 - Dry density versus cure time (S_CDW)

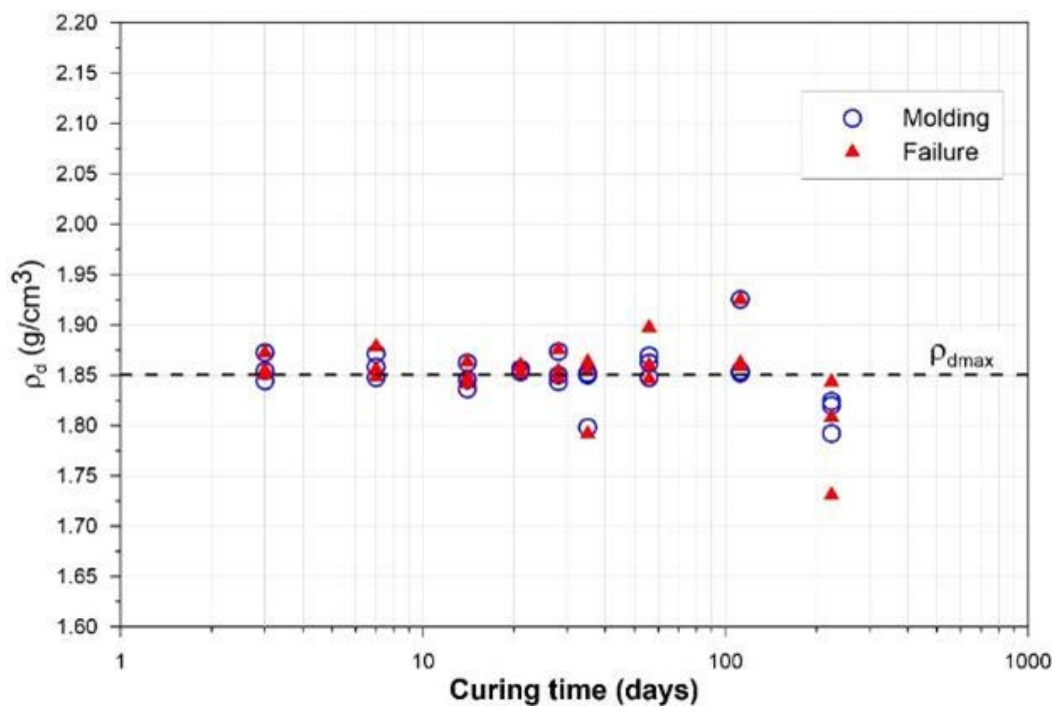

Figure 12 - Unconfined Compressive Strength (CDW_1)

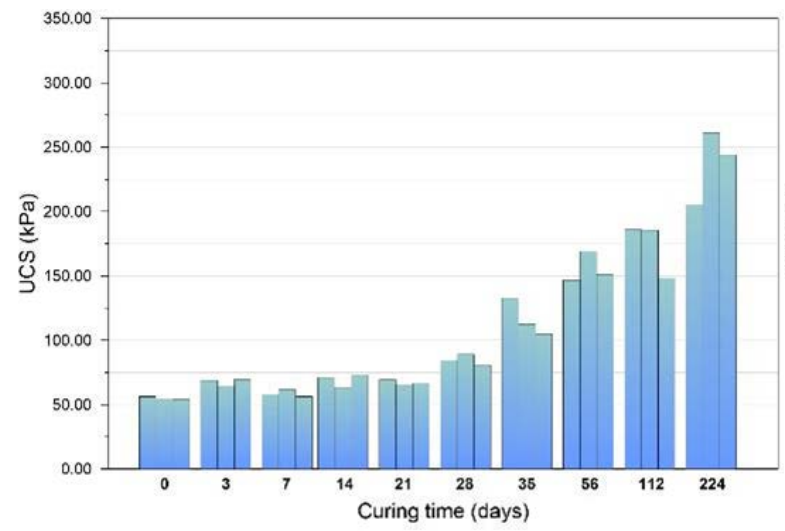

(a) UCS versus curing time

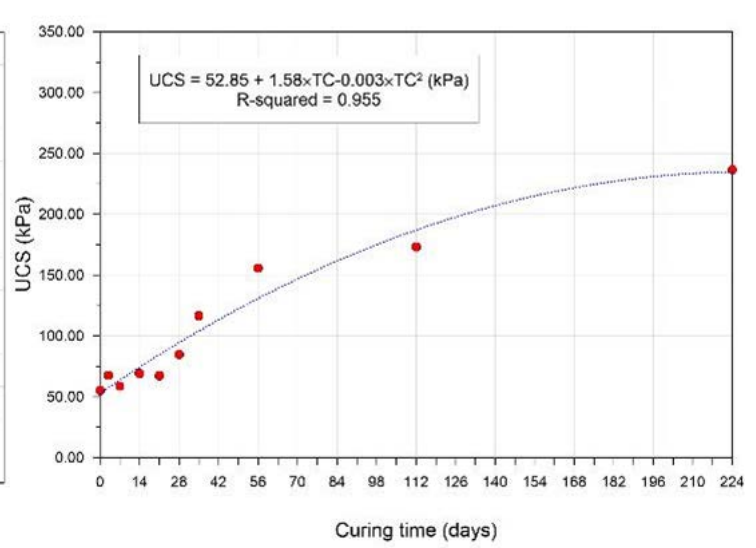

(b) Fit equation 
Figure 13 - Unconfined compressive strength (S_CDW)

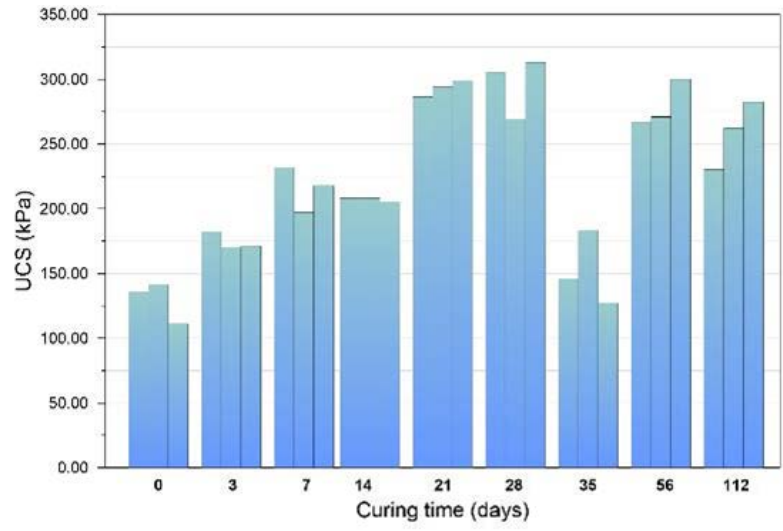

(a) UCS versus curing time

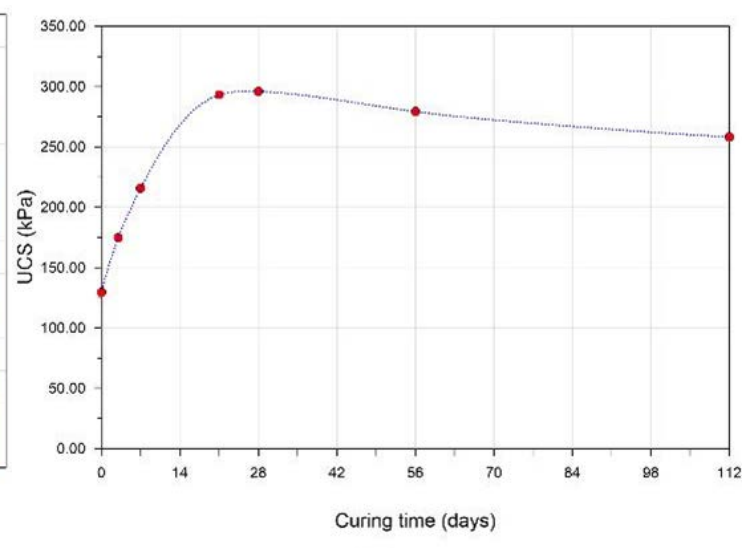

(b) Fit equation

The increase of resistance values of S_CDW mixture may also be associated with the presence of concrete and cementitious mortar grains.

The results of compaction tests can be used to interpret the behavior of CDW resistance (Table 1 and Figure 3). The S_CDW sample show maximum dry density $\left(1.850 \mathrm{~g} / \mathrm{cm}^{3}\right)$ higher than CDW_2 $\left(1.589 \mathrm{~g} / \mathrm{cm}^{3}\right)$, and consequently show void ratio lower. Thus, the resistance of S_CDW sample, should be higher than CDW_2 sample, confirming the resistance results. On the other hand, the S_CDW sample show optimum moisture content (13.20\%) lower than CDW_2 sample CDW_2 (19.70\%), showing that the water volume is lower for this sample and consequently the void ratio is lower. Again, it is noted that resistance results are consistent.

The variation in the unconfined strength over time can be evaluated through normalized values. In this case, the values of unconfined compressive strength (UCS) were divided by a reference value (UCS $\mathrm{Uref}_{\text {r. }}$, which is the value corresponding to the initial time equal to 0 days. This analysis allows evaluating the increase of strength over time. Figure 15 indicates that the CDW_1 sample, composed exclusively of waste material showed an increase of about 4.3 times of the initial strength, when compared with the final strength (224 days). It is important to note that the composition of this sample is waste material fines with a grain size smaller than $0.42 \mathrm{~mm}$. This behavior confirms the observations of Poon, Qiao and Chan (2006) where the authors emphasize that the self-cementing property of the waste material is governed by the fine fraction of the sample, but also due to the composition of the fraction and the reactive phase presented by these fines. 
Figure 14 - Void ratio as a function of curing time

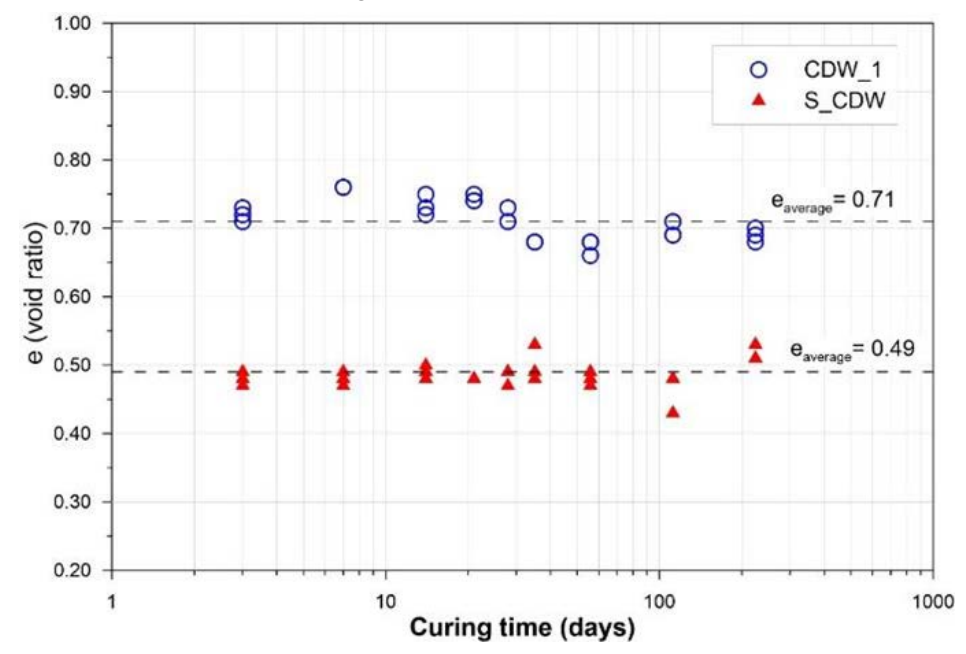

Despite of the S_CDW sample shows values of strength higher than CDW_1, the S_CDW sample did not present the same increase in strength over time. The maximum increase was 2.3 times comparing initial (0 days) and final strength (112 days). It is important to note that for this sample the construction waste percentage is lower than in the CDW_1 sample. Results also show that for the S_CDW sample the increase of strength over time was more pronounced than CDW_1 until 28 days of cure. After this time, the strength values stabilized and the CDW_1 strength values increased significantly. Additionally, the waste material used for the CDW_2 mixture, had larger particles than the particles in the CDW_1 sample, having a much lower fines content. Consequently, a smaller increase in strength was observed after 28 days of cure, with a tendency for values to stabilize in a much shorter curing period than that of the CDW_1 sample.

Parameters as void ratio, density and moisture content allow explaining the resistance behavior of the waste samples. However, the rate of resistance development can only be explained through the composition of the samples, which indicate the selfcementing effect over time.

For the waste samples it was observed that the increasing of the resistance rate development is higher for shorter cure times. This is because there is a large amount of hydraulic phases (anhydrous grains) and pozzolanic active. The presence of concrete and cementitious mortar grains contributes with the resistance behavior.

However, the analyses lead to the conclusion that even the use of the CDW in its original grain size distribution and mixed with soil, provide a considerable increase in the unconfined compressive strength. The feasibility of using this material, in addition to providing a proper disposal option, contributes to the increase in unconfined compressive strength.

\section{Modulus of Elasticity (E)}

Figure 16 shows the mean normalized values of the tangent modulus as a function of curing time, for the CDW_1 and S_CDW samples. The results indicate that the samples provided increased stiffness over time. For the CDW_1 sample, the observed increase in stiffness, relative to the test specimens without curing time, was $20 \%, 17 \%, 32 \%, 34 \%, 49 \%, 77 \%$, $94 \%, 110 \%$ and $180 \%$ for $3,7,14,21,28,35,56$, 112 and 224 days of curing. For the S_CDW sample, the observed increase in stiffness was $21 \%$, $39 \%, 48 \%, 55 \%, 47 \%, 42 \%$ and $52 \%$ for $3,7,14$, 21, 28, 56 and 112 days. Again, the results indicate that the stiffness gain is more pronounced for samples consisting of construction waste alone. However, for the soil-CDW mixture the increase, though in reduced proportions, was also evident.

Similar to the behavior of the unconfined compressive strength, the increase in stiffness for the CDW_1 sample continues to increase up to 224 days of curing, whereas for the mixture (S_CDW) the increase is more pronounced up to 28 days indicating a possible stabilization of the values.

The increase in stiffness over time can be attributed to the presence of non-hydrated cement, again demonstrating the self-cementing behavior characteristic of construction and demolition waste due to the addition of water that provides the occurrence of new reactions in non-inert particles.

Wallace (2011) and Grubba (2009) studied the selfcementing effect of construction waste through the increase in stiffness. Compared with the values observed in this study, the rate of increase in 
stiffness was very close. Wallace (2011) and Grubba (2009) reported an increase of 195\% and $268 \%$ respectively for a 90 day curing time. However, the stiffness values found were much higher than the values of the present research (Figure 17). The difference between the values can be explained by the effort difference used for the compaction of the specimens. In this work the standard effort, corresponding to $600 \mathrm{~kJ} / \mathrm{m}^{3}$, was used, while the other authors used the intermediate effort, corresponding to $1300 \mathrm{~kJ} / \mathrm{m}^{3}$. Besides that, the influence of important factor such as composition of CDW and physical, chemical and mineralogical characteristics also be considered.

\section{Scanning Eléctron Microscopy (SEM)}

After the unconfined compressive strength tests, the samples were submitted to an SEM test in order to verify their internal structure. In addition, a dispersive energy spectrometer was used for qualitative determination of the chemical composition of the observed structural elements. The analyses were performed on samples with different curing periods.

Figure15 - Normalized strength values as a function of curing time

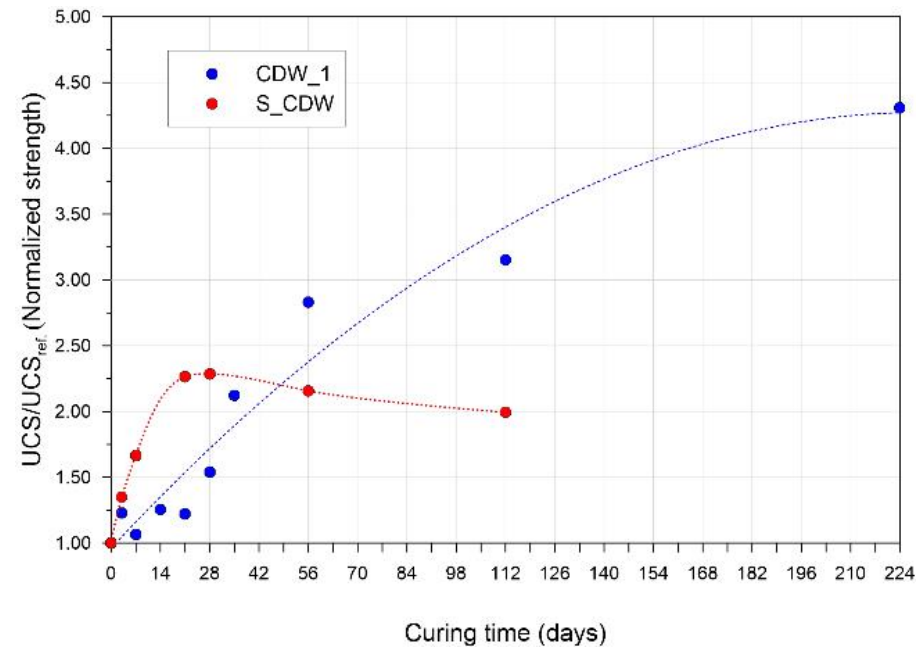

Figure 16 - Normalized values of the tangent modulus $\left(E_{t}\right)$

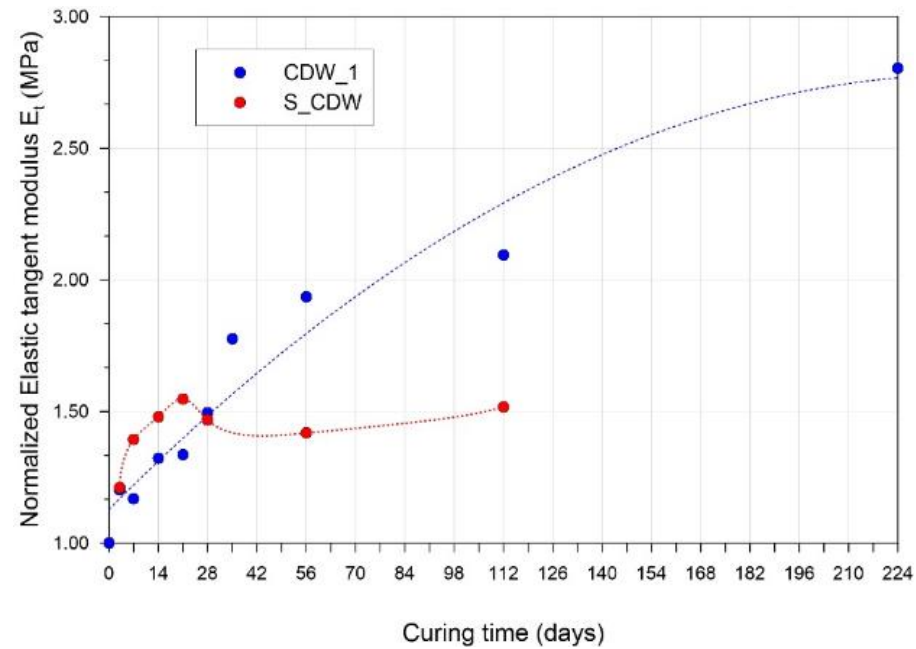


Figure 17 - Comparison of tangent modulus values $\left(E_{t}\right)$

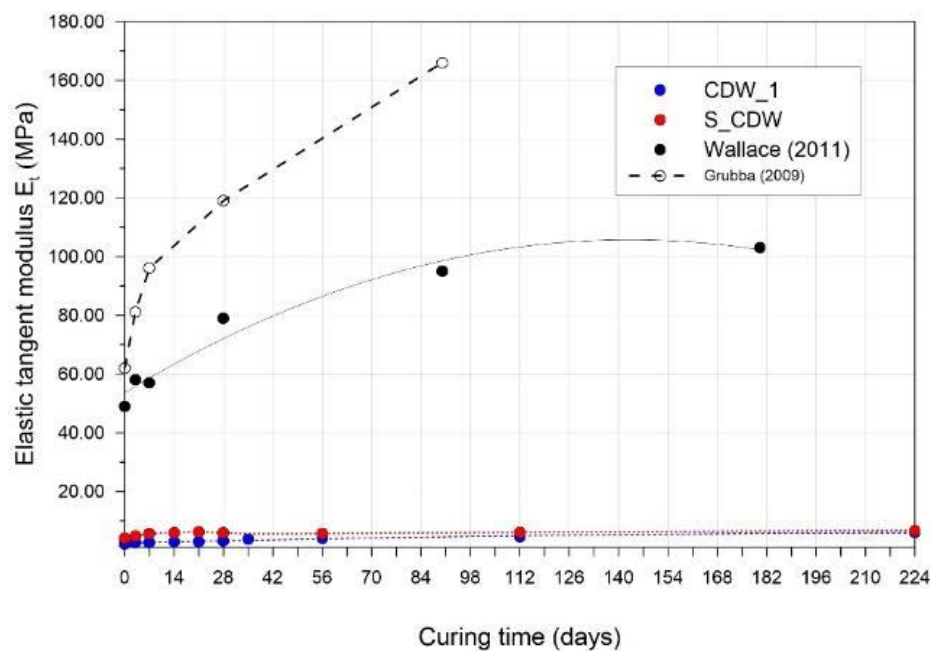

Figure 18 shows the micrograph for the CDW_1 sample without cure time. There is no evidence of cement hydration product. Figure 19 shows the micrograph for the CDW_1 sample, with the strength test performed after 35 days of molding, i.e., with a curing period of 35 days. The rupture of the specimens indicated that the strength increased about $200 \%$ relative to the uncured sample. This increase may occur because non-inert particles of cement may have reacted causing increased strength.

The presence of calcite, detected in the sample (Figure 6), can be associated with concrete and cementitious mortar found in CDW. In Figure 19, there is evidence of the formation of structures similar to microcrystals of calcite and ettringite crystals, mainly because the spectral diagram indicates the presence of S. Moreover, it is possible to visualize the presence of microcrystals of calcium carbonate (rhombohedral morphology of crystals). The image also presents an aspect of contamination.

The spectral diagram indicates the presence of $\mathrm{Si}$, associated with the presence of cement, and also to the quartz, present in the rocks. The elements $\mathrm{Ca}$, $\mathrm{Al}, \mathrm{Mg}, \mathrm{S}, \mathrm{Si}$, identified in the sample, are cement hydration products. Therefore, the occurrence of reactions associated with the cement hydration process and consequently the strength gain is clearly evident.
Scrivener (1989) points out that calcium hydroxide $(\mathrm{CH})$ is the only cement hydration product that has a defined crystalline structure, forming slightly hexagonal plates. In Figure 20 it is possible to see this type of structure, associated with the presence of ettringite, filling the pores of the soil-CDW matrix. The matrix shown in Figure 20 corresponds to the micrograph for the S-CDW sample, with the strength test performed after 56 days of molding cure. For these samples, the increase in strength was also approximately $200 \%$ over the uncured sample.

The spectral diagram indicates the presence of $\mathrm{Ca}$, $\mathrm{Al}, \mathrm{Si}$ and $\mathrm{Fe}, \mathrm{S}$, which are hydration products of cement and are characterized by the presence of ettringite. Ettringite is detected in the first ages of hydration. As the hydration reactions continue, ettringite turns into monosulfate (AFm). Thus, the presence of ettringite indicates that the reactions are occurring from the anhydrous grains, explaining the resistance gain over time (self-cementing).

In general, the use of the SEM technique helped to identify internal structures characteristic of the cement hydration process, and consequently of the increase in strength observed in the unconfined compressive strength tests. The construction waste promoted new reactions both in matrices that used the pure CDW, with particle size less than $0.42 \mathrm{~mm}$ (CDW_1), as well as in matrices that used the most granular construction waste mixed with natural soil (S_CDW). This behavior explains the results of Silva et al. (2015), where soil mixtures with higher CDWs showed higher strength values. 
Figure 18 - Micrograph for sample CDW_1 (no cure)
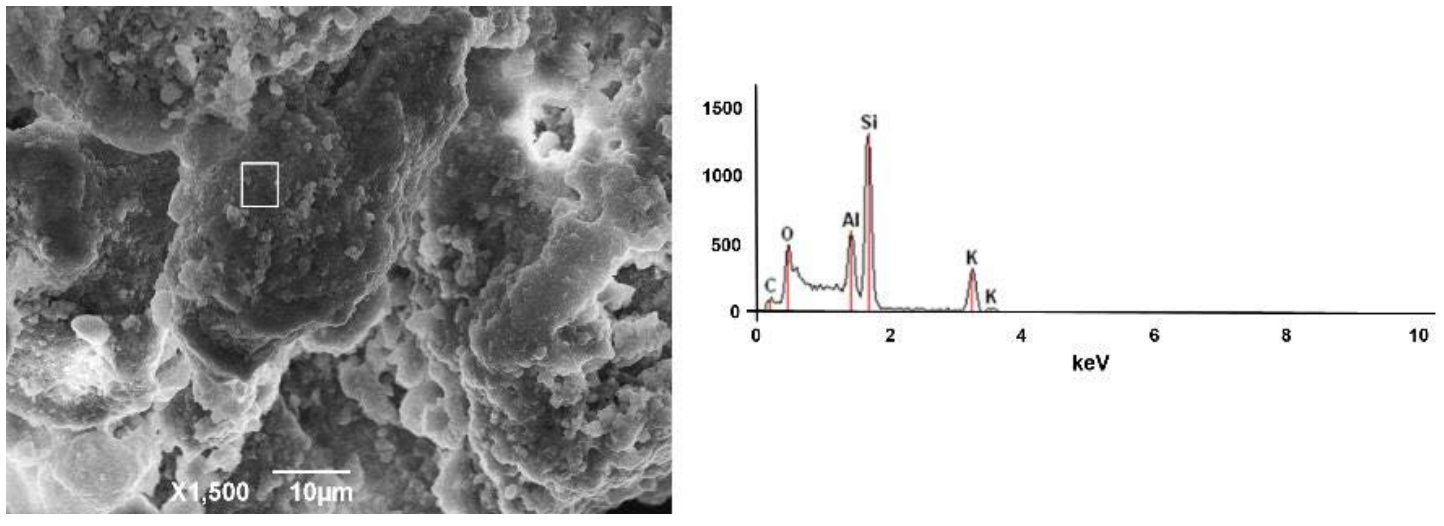

Figure 19 - Micrograph for sample CDW_1 (35 days)

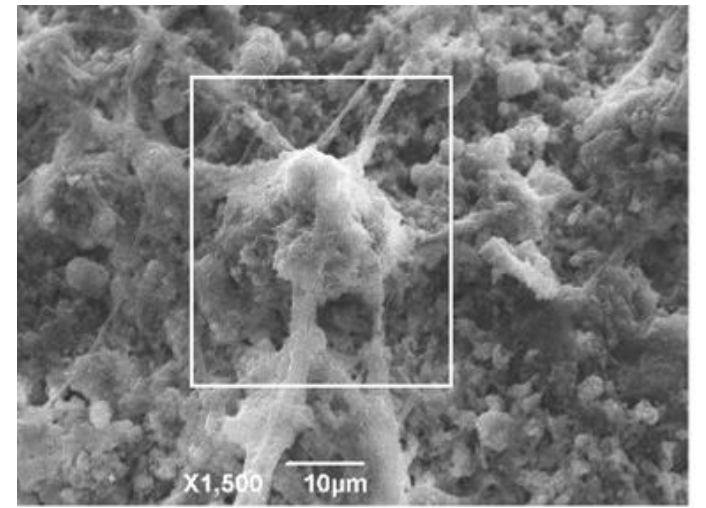

(a) $1500 x$

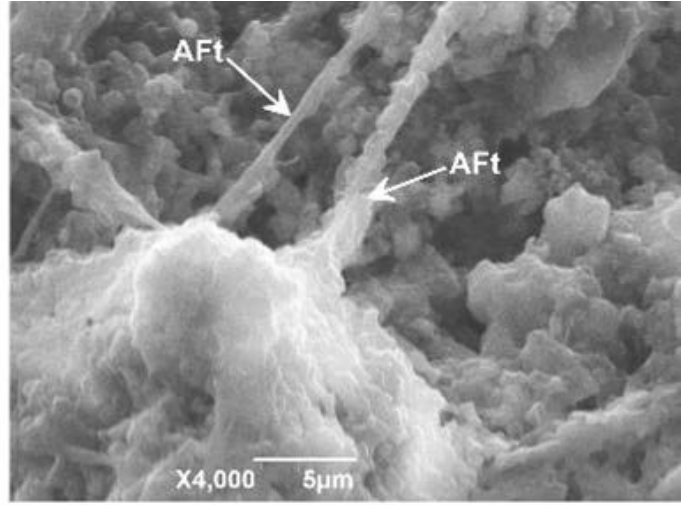

(b) $4000 x$

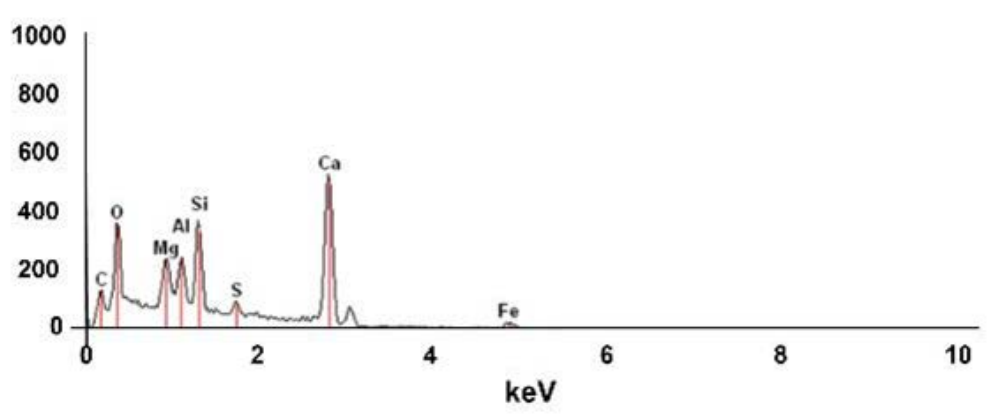


Figure 20 - Micrograph for sample S_CDW (56 days)

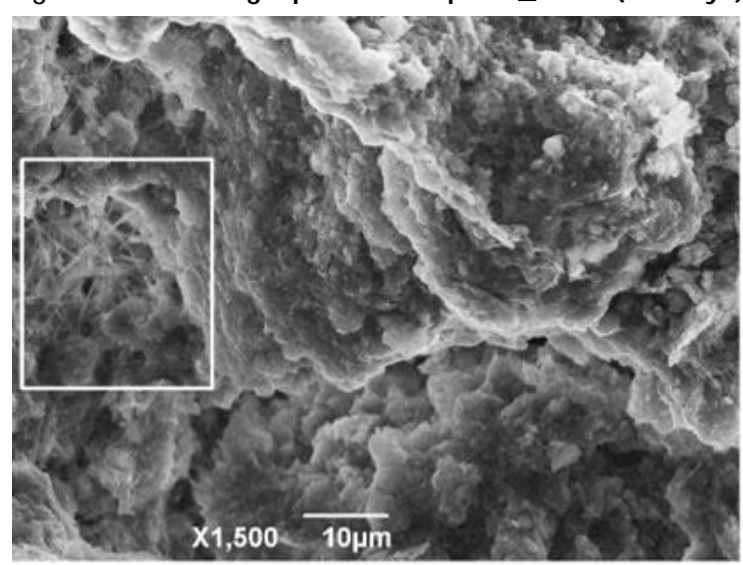

(a) $1500 x$

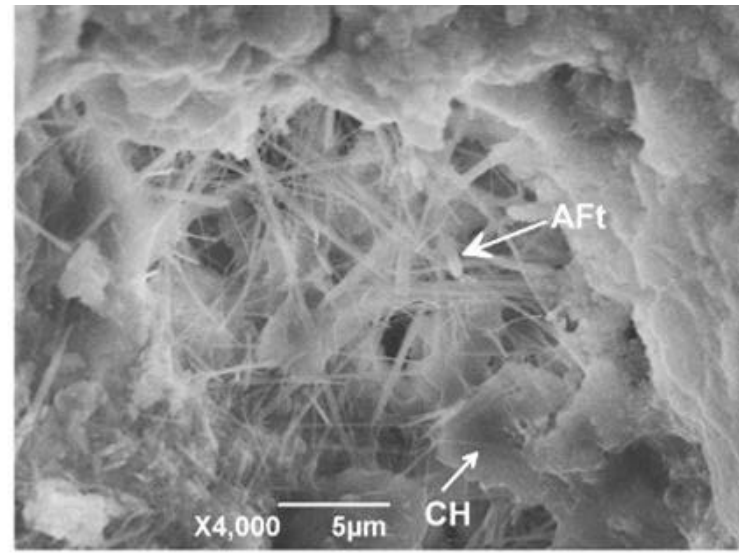

(b) $4000 x$

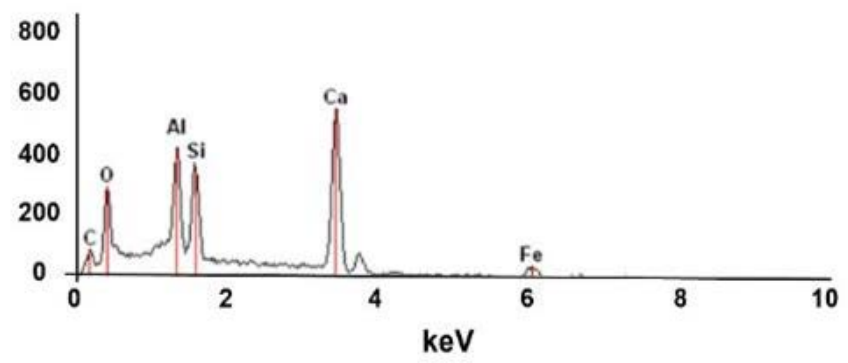

\section{Final considerations}

This work presented a study of the mechanical performance of construction and demolition waste (CDW) over time for pavement support layers purpose, in order to evaluate the self-cementing effect of this specific material (POON; QIAO; CHAN, 2006; GÓMEZ, 2011; SILVA et al., 2015, GRUBBA, 2009; WALLACE, 2011). The objective was to evaluate whether the addition of construction waste could also be beneficial to the mechanical behavior of the soil, providing incentive to partially replace soil with construction waste and reducing the exploitation of natural soil deposits for the construction of base and sub-base pavements in roads. The main results are as follows:

(a) the evaluation of the pozzolanic activity through the Modified Chapelle Method indicated that the material cannot be considered pozzolan, mainly due to the absence of the presence of pozolanic materials found in bricks and tiles. The self-cementing effects, presented in this paper, can be associated with the hydration of anhydrous grains, explaining the resistance gain over time;

(b) moreover, the $\mathrm{pH}$ values may be attributable to concrete and cementitious mortar fragments are already carbonated. The CDW_1 shows a $\mathrm{pH}$ value lower than CDW_2, probably because this sample is composed of small fractions of concrete and cementitious mortar, possibly carbonated. The
CDW_2 sample is composed of particles larger than the CDW_1, where non-carbonated fractions can be found or the presence of anhydrous grains;

(c) X-ray diffraction indicated the presence of calcite, which is characterized as one of the principal cementitious minerals. The presence of this mineral confirmed the presence of concrete, which was visually observed in the sample. However, it is important to carry out thermal analysis tests for the better characterization of the reactive phases and the low crystallinity;

(d) the control of the dry density of the specimens during molding and before rupture allowed strength gain, attributable to variation in this parameter, to be discarded. Increasing the dry density increases the strength of the material because it increases the degree of compaction of the sample. Indeed, the control of this research was efficient and indicated no significant variation in the dry density up to the period of 224 days;

(e) unconfined compressive strength results indicated a fairly significant increase in strength over time. It is noteworthy that the samples that used CDW exclusively in their composition showed increasing behavior over time. The samples that used the soil and CDW mixture showed an increase in strength with a tendency toward strength stabilization. This behavior confirmed the observations of Poon, Qiao and 
Chan (2006) where the self-cementing properties of the construction waste were found to be associated with the amount of fraction of fine material, related with the amount of concrete and cementitious mortar present in the sample. However, the analyses lead to the conclusion that even the use of CDW in its original grain size distribution mixed with soil, provides a considerable increase in the unconfined compressive strength. Additionally, parameters such as waste mineralogical composition, reactivity of finest particles, density, void ratio and moisture content of samples should be considered;

(f) the self-cementing effect of the construction waste was also evaluated by means of the stiffness of the specimens, because the cement is a material, added to soil, that provides an increase of the modulus of elasticity. The results of this study demonstrate an increase in stiffness both in the construction waste sample (CDW_1) as well as in the combined soil-waste sample (S-CDW). Therefore, the self-cementing effect of construction waste is again evident; and

(g) the use of scanning electron microscopy proved to be a useful tool for evaluating the development of the internal reactions that occur in the matrix material. Through these analyses it was evident that construction waste promotes strength gain through reactions associated with the presence of cement.

In general, the results presented in this work contribute to the understanding of strength gain in construction and demolition waste. Although the waste is composed of concrete, cementitious mortar and soil showing a non-pozzolanic behavior, the resistance gain over time was observed. This behavior can be associated with the hydration of anhydrous grains or pozzolanic reactions, in case of use pozzolanic cement in concrete and cementitious mortar. In addition, the beneficial effects of soilCDW mixtures have been proven, encouraging the use of this material as a substitution for natural soil and a reduction in the exploitation of natural soil deposits. It is important to highlight that this work is a contribution to this specific material and further analysis are fundamental to different materials.

\section{References}

ARM, M. Self-Cementing Properties of Crushed Demolished Concrete in Unbound Layer: results from triaxial test and field test. Waste Management, v. 21, p. 235-239, 2001.
ARULRAJAH, A.; PIRATHEEPAN, J.; DISFANI, M. M., BO, M. W. Geotechnical and Geoenvironmental Properties of Recycled Construction and Demolition Materials in Pavement Subbase Applications. Journal of Materials in Civil Engineering, v. 25, n. 8, p. 1077-1088, 2013.

ASSOCIAÇÃO BRASILEIRA DE NORMAS TÉCNICAS. NBR 15895: materiais pozolânicos: determinação do teor de hidróxido de cálcio fixado: método Chapelle modificado. Rio de Janeiro, 2010.

\section{ASSOCIAÇÃO BRASILEIRA DE NORMAS} TÉCNICAS. NBR 6457: amostras de solo: preparação para ensaios de compactação e ensaios de caracterização. Rio de Janeiro, 2016b.

\section{ASSOCIAÇÃO BRASILEIRA DE NORMAS TÉCNICAS. NBR 6458: grãos de pedregulho retidos na peneira de abertura 4,8 mm: determinação da massa específica, da massa específica aparente e da absorção de água. Rio de Janeiro, 2017.}

ASSOCIAÇÃO BRASILEIRA DE NORMAS
TÉCNICAS. NBR 7181: solo: análise
granulométrica. Rio de Janeiro, 2018.

ASSOCIAÇÃO BRASILEIRA DE NORMAS TÉCNICAS. NBR 7182: solo: ensaio de compactação. Rio de Janeiro, 2016a.

BLANKENAGEL, B. J. Characterization of Recycled Concrete For Use as Pavement Base Material. Provo, 2005. 66 f. Master Dissertation Department of Civil and Environmental Engineering Brigham Young University. Provo, 2005.

EVANGELISTA, L. et al. Physical, Chemical and Mineralogical Properties of Fine Recycled Aggregates Made From Concrete Waste.

Construction and building materials, v. 86, p. 178-188, 2015.

GÓMEZ, A. M. J. Estudo Experimental de Um Resíduo de Construção e Demolição (RCD) Para Utilização em Pavimentação. Brasília, 2011. 123 f. Dissertação (Mestrado em Engenharia Civil) - Escola de Engenharia, Universidade de Brasília, Brasília, 2011.

\section{GRUBBA, D. C. R. P. Estudo do}

Comportamento Mecânico de Um Agregado

Reciclado de Concreto Para Utilização na Construção Rodoviária. São Carlos, 2009. 139 f. Dissertação (Mestrado em Engenharia Civil) Escola de Engenharia de São Carlos, Universidade de São Paulo, São Carlos, 2009. 
MOTTA, R. S. Estudo Laboratorial de Agregado Reciclado de Resíduo Sólido da Construção Civil para Aplicação em Pavimentação de Baixo Volume de Tráfego. São Carlos, 2005. 134 f. Dissertação (Mestrado em Engenharia Civil) - Escola Politécnica da Universidade de São Paulo, Departamento de Engenharia de Transportes, São Carlos, 2005.

POON, C. S.; QIAO, X. C.; CHAN, D. The Cause and Influence of Self-Cementing Properties of Fine Recycled Concrete Aggregates on the Properties of Unbound Sub-Base. Waste Management and Research, v. 26, p. 1166-1172, 2006.

SANGIORGI, C.; LANTIERI, C.; DONDI, G. Construction and Demolition Waste Recycling: an application for road construction. International Journal of Pavement Engineering, p. 1-8, 2014.

SCRIVENER, K. L. The Microstructures of Concrete. In: SKALNY, J. Materials Science of Concrete. New York: The American Ceramic Society, 1989.
SILVA, T. B. et al. Construction and Demolition Waste (CDW) Used in Reinforced Soil Mixtures For Pavement Applications. In: PAN-AMERICAN CONFERENCE ON SOIL MECHANICS AND GEOTECHNICAL ENGINEERING, 15., Buenos Aires, 2015. Proceedigns... Buenos Aires, 2015.

WALLACE, F. S. Estudo Sobre a Aplicação de Agregado Reciclado de Concreto em Construção de Pavimentos. São Carlos, 2011. 116 f. Dissertação (Mestrado em Engenharia Civil) - Escola de Engenharia de São Carlos, Universidade de São Paulo, São Carlos, 2011.

\section{Acknowledgements}

The authors would like to express their appreciation to the CNPq (Process No. 448606 / 2014-3), for their financial support and to the CBPF for providing the infrastructure for the performance of the Scanning Electron Microscopy tests. Furthermore, the authors appreciate the helpful corrections and suggestion from the reviewers.

\section{Fabiana Artuso}

Departamento de Engenharia Civil | Universidade Estadual de Maringá | Av. Colombo, 5790 | Maring[a - Paraná - Brasil | CEP 87020-900 | Tel.: (44) 3011-4322 | E-mail: fabianaartuso@gmail.com

\section{J uliana Azoia Lukiantchuki}

Departamento de Engenharia Civil | Universidade Estadual de Maringá | E-mail: jazoia@yahoo.com.br

Revista Ambiente Construído

Associação Nacional de Tecnologia do Ambiente Construído

Av. Osvaldo Aranha, 99 - 3o andar, Centro

Porto Alegre - RS - Brasil CEP $90035-190$

Telefone: +55 (51) 3308-4084

Fax: +55 (51) 3308-4054

www. seer. ufrgs. br/ ambienteconstruido

E-mail: ambienteconstruido@ufrgs.br

\section{(i)}

This is an open-access article distributed under the terms of the Creative Commons Attribution License.

Evaluation of the self-cemeting effect of Construction and Demotion Waste (CDW) on mechanical performance over 77 time for pavement support layers purpose 